\title{
Role of Victim in the Criminal Justice System
}

MEERA MATHEW

\begin{abstract}
The victims of crime are those who have formerly endured injury or are possibly suffering as an outcome of crimes having been committed. The direct family or dependants of the direct victims, who are harmfully affected, are also included within the meaning of the term "Victims". The predicament of the victims does not finish with the crime but it persists. It may even increase, following the crimes; since they have to face the rigors of the actuality, such as deficient support system, dearth of social backing, and sense of anxiety. They also experience the intricacy of police inquiry, magisterial investigation and criminal trial. The impact of victimization on different kinds of victims due to different types of crimes has been varied such as physical, psychological and financial. Through this paper writer has endeavored to check the situation of victims of crime in India and the criminal justice system. It is apparent that the desolation of the victims have not been effectively addressed or even gone out of contemplation. Victims are disregarded, may, forgotten. The paper also stresses the need to provide support to crime victims. The author of the present paper has also recommended some of the imperative steps that are to be implemented by the law enforcement agencies in India to improve the position of victims in the criminal justice system.
\end{abstract}

Key Words: Victim and Criminal Justice System

In wake of the many atrocities that seemed to be committed against the accused person in our criminal justice system the focus had been shifted from the victim upon maintaining, protecting and safeguarding the rights of the accused whereas, it should have been the other way round; there was no particular reason as to why this paradigm shift occurred where all the attention came to be focused upon the person who had committed the crime instead of the person who is the real sufferer of the act committed by the wrongdoer. When a crime is committed the actor does that act to achieve his ulterior motives and which he finally does and adding to that he all the more gets the benefit starting right from the point of his apprehension by the concerned authorities to his trial and also in the final verdict which is awarded by the courts keeping in view the mitigating circumstances; and in the all this the poor victim suffers at all the stages, there is nobody to look after him, even the state who is the protector of the victim and defends the victim in the criminal proceedings is oblivious towards his predicaments.

The term "victim" is derived from the Latin word "victima". The concept of victim was well known in the ancient civilization, especially in Babylonia, Palestine, Greece and Rome. The modern concept of victim of crime may be traced from the writings of 'Mendelsohn' the criminologist, who is known as the father of victimology (Kannan, 2009).

In India the various organs of the State, especially the judiciary, are now recognizing the role of victim. This reform started to take place a little after the 1970s where the State started realizing that its not the accused in a criminal proceeding who should be taken care of but it is the victim of that crime whose rights are 
important. The past few decades have experienced a revolution in the field of victimology and the way in which the society deals with the victims of crime, but still in India there is a lot of scope for improvement in the way the victims are dealt with under the criminal justice system.

\section{STATUTES AND CONSTITUTIONAL PROVISIONS}

There are provisions under the Indian law, which come to the rescue of the victim of a crime, which can be found under the Constitution and also under the Code of Criminal Procedure, but to the victim's misfortune these are sparingly used by the courts while delivering their judgments. On the other hand it is heartening to see that various High Courts and the Supreme Court have in the last two decades have pragmatically applied these laws to the benefit of the victim not only in the cases where the hardship is caused to the victim by a private individual but also when the harm is caused by an instrumentality of the State (Srinivas \& Mathew, 2007).

Code of Criminal Procedure (Amendment) (CrPC, 2(wa), 2008) ${ }^{1}$ defines 'victim' which provides that apart from the individual who has suffered himself, his family members and legal heirs would also come under the purview of 'victim.' The latter part of the new provision is very effective as when a crime takes place it is not only the actual victim who suffers but also it is the family members and his legal heirs who are the sufferers, if for example the victim is a deceased who was the sole bread earning member of the family and if he is no more then the whole family faces the wrath of the cruel world and there is nobody to support them. Therefore, putting the family members and the legal heirs of the victim under the definition of 'victim' is a welcome step. Also as per the doctrine of sovereignty, it is the duty of the sovereign to protect its people not only from the external aggression but also from the internal disturbances. Failing to protect a citizen against fellow citizens is also dereliction of duty on the part of the State. In this light, it is interesting to note that the incorporation of the word 'charged' in the amendment Act of 2008 means that the State will protect the victim of a crime against the accused whether he is convicted or acquitted (CrPC, 1, 2008).

Though the Code of Criminal Procedure, 1973 recognizes the right of victim in a pale and limited sphere, it is not at all comprehensive enough. Section (357, CrPC, 1973) ${ }^{2}$ though recognizes the award of compensation to the victim, it has not developed into a branch of victimology at all. The Law Commission of India in its $41^{\text {st }}$ report has recommended that power of awarding compensation by criminal courts to the victim of crime must be exercised by the courts in a sense of reality. The Supreme Court also in a number of decisions held that Section 357 Code of Criminal Procedure empowers the criminal court to award compensation to the victim, and this power should be exercised liberally so as to meet the ends of justice. Nevertheless, awarding monetary compensation does not uplift the right and status of the victim at par with the right and status enjoyed by the accused before the criminal justice delivery system (Prakash, 2008).

The right of a victim of crime to receive compensation was recognized even under the Code of Criminal Procedure, 1898 but was available only where a substantive sentence of fine was imposed and was limited to the amount of fine actually realized. Section 357 (3) Code of Criminal Procedure 1973 permits the grant of compensation even where the accused is not sentenced to fine. However, the courts as said above invoke this provision sparingly and inconsistently.

The 152nd Report of the Law Commission had recommended the introduction of Section.357-A prescribing inter alia that compensation be awarded at the time of 
sentencing to the victims of the crime Rs.25,000/- in the case of bodily injury, not resulting in death; Rs.1,00,000/- in the case of death. The 154th Report of the Law Commission of India noticed that its earlier recommendation had still not been given effect to by the government. It went one step further and recommended that it was necessary to incorporate "a new section 357 -A in the Code to provide for a comprehensive scheme of payment of compensation for all victims fairly and adequately by the courts. Heads of compensation are for (i) for injury;(ii) for any loss or damage to the property of the claimant which occurred in the course of his/ her sustaining the injury and (iii) in case of death from injuryresulting in loss of support to dependants". This recommendation also has not been acted upon by the government.

The Code of Criminal Procedure has recognized the principle of victim compensation in some of its other provisions also, such as Section $(358, \mathrm{CrPC}, 1973)^{3}$ the court is empowered to order a person to pay compensation to another person for causing a police officer to arrest such other person wrongfully. Also section 250 authorizes magistrates to direct complainants or informants to pay compensation to people accused by them without reasonable cause.

The Constitution of India provides for the protection and rehabilitation of the victim in various ways impliedly under its provisions. The Fundamental Rights under Part III and the Directive Principles of the State Policy under Part IV of the Constitution of India provide for various clauses under which the State stretches a helping hand to the victim and embraces him. Under a. 38 of the Constitution the State has to secure a social order for the promotion and welfare of the people, also under article 41 of the Constitution (Article$41)^{4}$ the State provides for upliftment of the people who are generally incapacitated to help themselves and this provision will also include a hapless victim.

\section{THE MALIMATH COMMITTEE}

Recent local developments require to be noticed. The notification of the Government of India constituting the Committee on Reforms of Criminal Justice System, chaired by Justice V.S. Malimath (hereafter 'Malimath Committee') was uncharacteristically candid in its lamentation that "People by and large have lost confidence in the Criminal Justice System... Victims feel ignored and are crying for attention and justice" (Government of India, Report, 2003, p. 75). In its turn the Malimath Committee, after making extensive recommendations to ensure that "the system must focus on justice to victims" (Government of India, Report, 2003, p. 270), has concluded that "criminal justice administration will assume a new direction towards better and quicker justice once the rights of victims are recognized by law and restitution for loss of life, limb and property are provided for in the system (Government of India, Report, 2003, p. 271). While largely concurring with the recommendations of the Law Commission of India in relation to witness protection the Malimath Committee concludes "Time has come for a comprehensive law being enacted for protection of the witness and members of his family" (Government of India, Report, 2003, p. 152, para 11.3).

The principal criticism of the Malimath Committee is that in its single- minded focus on shifting the system from being accused-centric, an assumption not borne out by any systematic empirical analysis, and in its over eagerness to make it address the needs of victims, it adopts the 'either/or' approach. It jettisons the principle of presumption of innocence, which it views as a barrier to discovering the truth. Prof. Upendra Baxi criticism is that "Instead of doing any sustained empirical work bearing on so crucial a matter, the Report relies merely on 'commonsense' expressed ad nauseum in judicial reiteration of the maxim: "it is better that ten guilty persons may escape rather than one innocent person may suffer" (Baxi, 2003). 


\section{INTERNATIONAL TREATIES AND COVENANTS}

Making a reference of the international treaties and covenants we come across various protections and rights, which favor the victim of a crime committed against him. The Universal Declaration of Human Rights, 1948 provides for a right of recognition to everyone as a person before the law (Article- 6, 1948) , $^{5}$ one of its articles provides for the equality before law and entitlement without any discrimination to equal protection of the law (Article-7, 1948) $^{6}$, also the Universal Declaration of Human Rights provides that everyone has an effective right against violation of their fundamental rights provided by the constitution or by law (Article- 8,1948$)^{7}$. Similarly, the International Covenant on Civil and Political Rights, 1966 also provides that any person's whose rights are violated shall have an effective remedy notwithstanding that the violation has been committed by persons acting in their official capacity (Article-2 (3) (a), 1966) ${ }^{8}$, also that all persons shall be equal before the courts and tribunals ${ }^{9}$.

The International Criminal Court was established in 1998 to help end impunity for the perpetrators of the most serious crimes of concern to the international community. It is an independent organization to help the distressed victims of heinous crimes committed across the globe. One Josef Kony is on the top most of the list of the persons to be prosecuted by the International Criminal Court, he is the head of he Lord's Resistance Army in Uganda who murders people, sexually assaults women and kidnap children, makes them soldiers and makes them kill their own parents for his benefits. Taking note of such serious crimes against the humanity the International Criminal Court has come to the rescue of the victims of these crimes so that their sufferings may end and the people of Uganda may have a better future.

\section{JUDICIAL APPROACH}

Now if we have a look at the case laws we will see that the courts in the 1970s started recognizing the rights of the victim in the sense that the focus shifted from the accused to the victim and now the victim started getting recognition and his plight started coming to an end. In the case of Maru Ram and ors. v. UOI and ors (All India Reporter 1980 SC 2147, 1980 Criminal Law Journal 1440, (1981) 1 SCC107, (1981) SCC (Cri) 112, [1981] 1 SCR 1196). V. R. Krishna Iyer, J. (On behalf of himself and Y.V. Chandrachud, C.J. and P.N. Bhagwati, J.) said:

"Fidelity to the debate at the bar persuades us to remove a misapprehension. Some argument was made that a minimum sentence of 14 years' imprisonment was merited because the victim of the murder must be remembered and all soft justice scuttled to such heinous offenders. We are afraid there is a confusion about the fundamentals, in mixing up victimology with penology to warrant retributive severity by the backdoor. If crime claims a victim, criminology must include victimology as a major component of its concerns. Indeed, when a murder or other grievous offence is committed the dependants or other aggrieved persons must receive reparation and the social responsibility of the criminal to restore the loss or heal the injury is part of the punitive exercise. But the length of the prison term is no reparation to the crippled or bereaved and is futility compounded with cruelty. 'Can storied, urn or animated bust call to its mansion the fleeting breath?' Equally emphatically, given perspicacity and freedom from sadism, can flogging the killer or burning his limbs or torturing his psychic being, bring balm to the soul of the dead by any process of thanatology or make good the terrible loss caused by the homicide? Victimology, a burgeoning branch of humane criminal justice, must find fulfillment, not through barbarity but by compulsory recoupment by the wrong-doer of the damage 
inflicted; not by giving more pain to the offender but by lessening the loss of the forlorn, The State itself may have its strategy of alleviating hardships of victims as part of Article 41.

One of the very first cases in which the court awarded compensation to the victim was Palaniappa Gounder v. State of Tamil Nadu (All India Report, 1977 SC 1323) in this case the Supreme Court (SC) awarded ₹ 3000 to the victim and directed that the amount recovered shall be paid to the son and daughters of the deceased who had filed the petition in the High Court. This was a case wherein the SC achieved a proper blending of the offender rehabilitation and victim compensation (All India Report,1977, 2, p. 56). In the case of Hari Krishan and the State of Haryana v. Sukhbir Singh and ors (All India Report, 1988 SC 2127) the court said:

"The power under s. $357 \mathrm{CrPC}$ is a measure of responding appropriately to crime as well as reconciling the victim with the offender. It is, to some extent,a recompensatory measure to rehabilitate to an extent the beleaguered victims of the crime, a modern constructive approach to crime, a step forward in our criminal justice system... The payment by way of compensation must, however, be reasonable. What is reasonable may depend upon the facts and circumstances of each case."

One of the latest cases in which right of a victim has been given recognition is Mangal Singh and anr.v. Kishan Singh and ors (All India Report, 2009 SC 1535) wherein it has been observed thus:

"Any inordinate delay in conclusion of a criminal trial undoubtedly has highly deleterious effect on the society generally and particularly on the two sides of the case. But it will be a grave mistake to assume that delay in trial does not cause acute suffering and anguish to the victim of the offence. In many cases the victim may suffer even more than the accused. There is, therefore no reason to give all the benefits on account of the delay in trial to the accused and to completely deny all justice to the victim of the offence."

It is worth noting that the Constitutional Bench in Iqbal Singh Marwah and anr. v. Meenakshi Marwah and anr (All India Report, 2005 SC 2119). Where the court though in a different context, had also observed that delay in the prosecution of a guilty person comes to his advantage as witnesses becomes reluctant to give evidence and the evidence gets lost.

In one of the most recent cases the SC in Rattiram and ors. v. State of M.P. through Inspector of Police and Satyanarayan and ors. v. State of M.P. Incharge, Police Station Cantt (2012 (2) SCALE 593) observed:

"Be it noted, one cannot afford to treat the victim as an alien or a total stranger to the criminal trial. The criminal jurisprudence, with the passage of time, has laid emphasis on victimology, which fundamentally is a perception of a trial from the viewpoint of the criminal as well as the victim. Both are viewed in the social context. The view of the victim is given due regarded and respect in certain countries. In respect of certain offences in our existing criminal jurisprudence, the testimony of the victim is given paramount importance. Sometimes it is perceived that it is the duty of the court to see that the victim's right is protected. A direction for retrial is to put the clock back and it would be a travesty of justice to so direct if the trial really has not been unfair and there has been no miscarriage of justice or failure of justice."

\section{CONCLUSION}

Having regard of the present situation prevailing in our criminal justice system we need to appreciate as to who is the real victim in a criminal proceeding; is it the victim himself on whom the crime is committed and who is the sufferer of the crime committed against him or is it the accused who is posed as a victim right from the period of his apprehension when all his rights 
are taken care of, till the judgment is delivered taking into consideration the mitigating circumstances and when he is given all the benefit of doubt? I think it is the former who is the actual victim of a crime and not the latter who is impersonated as the victim, the present viewpoint needs to be reciprocated in the favor of the actual victim of a crime, it is his rights which should also be given due importance, especially by the State.

The accused and the victim should be treated at par, and neither of the party's rights should prevail over the others'. The courts which have now started giving humanly treatment to the victim is a welcome step and it should be taken a step further by either making an amendment in the statute such as the CrPC or enacting a new legislation which if not gives new rights to the victim, but safeguards those rights.

Having said all this it should be realized that the victim in a criminal proceeding needs care and protection at every stage, having already faced the misery of the offence committed against him, his hardships should not be aggravated but he needs to be compensated and rehabilitated.

MEERA MATHEW, LLB, Lawyer, Practicing in the Supreme Court, New Delhi, India.

\section{REFERENCES}

(1981) 1 SCC107

(1981) 1 SCR 1196

(1981) SCC (Cri) 112

1980 Criminal Law Journal 1440

2012 (2) SCALE 593

357, CrPC, (1973): Section-352, Code of Criminal Procedure, Act. 1973.

358, CrPC (1973): Section-358, Code of Criminal Procedure, Act. 1973.
CrPC, 1(2008): Code of Criminal Procedure (Amendment), Section-1, Act. 2008, p. 113

CrPC, 2(wa), (2008): Code of Criminal Procedure, Section2(wa), Act. 2008.

All India Report, 1977 SC 1323

All India Report, 2005 SC 2119

All India Report, 2009 SC 1535

All India Report,1977, 2, p. 56

All India Reporter 1980 SC 2147

Baxi, U. (2003). Introductory critique to the malimath committee on reforms of criminal justice system: Premises, politics and implications for human rights. Amnesty International India, 19, 76.

Government of India, Report (2003): Committee on Reforms of Criminal Justice System (Ministry of Home Affairs, 2003), p. 75, 157 (para, 11.3), $270 \& 271$.

Kannan, D. (2009). Rights of victim and the criminal procedure code: A critical study. MLJ , 3, 112.

Prakash, B. V. K. (2008). Victimology: The weak limb of criminal justice delivery system. Kerala Law Time, 4, 45.

Srinivas, M. \& Mathew, J. E. (2007). Victim and the criminal justice system in Inida: Need for a paradigm shift in the justice. Temida, 10 (2), 51-62.

\footnotetext{
1 "victim" means a person who has suffered any loss or injury caused by reason of the act or omission for which the accused person has been charged and the expression "victim" includes his or her guardian or legal heir.

${ }^{2}$ Order to pay compensation - (1) When a Court imposes a sentence of fine or a sentence (including a sentence of death) of which fine forms a part, the Court may, when passing judgment, order the whole or any part of the fine recovered to be applied- (a) in defraying the expenses properly incurred in the prosecution; (b) in the payment to any person of compensation for any loss or injury caused by the offence, when compensation is, in the opinion of the Court, recoverable by such person in a Civil Court; (c) when any person is convicted of any offence for having caused the death of another person or of having abetted the commission of such an offence, in paying compensation to the persons who are, under the Fatal Accidents Act, 1855 (13 of 1855), entitled to recover damages from the person sentenced for the loss resulting to them from such death; (d) when any person is convicted of any offence which includes theft, criminal misappropriation, criminal breach of trust, or cheating, or of having dishonestly received or retained, or of having voluntarily assisted in disposing of,
} 
stolen property knowing or having reason to believe the same to be stolen, in compensating any bona fide purchaser of such property for the loss of the same if such property is restored to the possession of the person entitled thereto. (2) If the fine is imposed in a case, which is subject to appeal, no such payment shall be made before the period allowed for presenting the appeal has elapsed, or, if an appeal be presented, before the decision of the appeal. (3) When a Court imposes a sentence, of which fine does not form a part, the Court may, when passing judgment, order the accused person to pay, by way of compensation, such amount as may be specified in the order to the person who has suffered any loss or injury by reason of the act for which the accused person has been so sentenced. (4) An order under this section may also be made by an Appellate Court or by the High Court or Court of Session when exercising its powers of revision. (5) At the time of awarding compensation in any subsequent civil suit relating to the same matter, the Court shall take into account any sum paid or recovered as compensation under this section.

${ }^{3}$ Compensation to persons groundlessly arrested - (1) Whenever any person causes a police officer to arrest another person, if it appears to the Magistrate by whom the case is heard that there was no sufficient ground for causing such arrest, the Magistrate may award such compensation, not exceeding one hundred rupees, to be paid by the person so causing the arrest to the person so arrested, for his loss of time and expenses in the matter, as the Magistrate thinks fit. (2) In such cases, if more persons than one are arrested, the Magistrate may, in like manner, award to each of them such compensation, not exceeding one hundred rupees, as such Magistrate thinks fit. (3) All compensation awarded under this section may be recovered as if it were a fine, and, if it cannot be so recovered, the person by whom it is payable shall be sentenced to simple imprisonment for such term not exceeding thirty days as the Magistrate directs, unless such sum is sooner paid.
${ }^{4}$ Right to work, to education and to public assistance in certain cases: The State shall, within the limits of its economic capacity and development, make effective provision for securing the right to work, to education and to public assistance in cases of unemployment, old age, sickness and disablement, and in other cases of undeserved want.

${ }^{5}$ Everyone has the right to recognition everywhere as a person before the law.

${ }^{6}$ All are equal before the law and are entitled without any discrimination to equal protection of the law. All are entitled to equal protection against any discrimination in violation of this Declaration and against any incitement to such discrimination.

7 Everyone has the right to an effective remedy by the competent national tribunals for acts violating the fundamental rights granted him by the constitution or by law.

${ }^{8}$ Each State Party to the present Covenant undertakes: (a) To ensure that any person whose rights or freedoms as herein recognized are violated shall have an effective remedy, notwithstanding that the violation has been committed by persons acting in an official capacity.

${ }^{9}$ A. David Ambrose, "The Right to Reparation for Victims of Violation of International Human Rights and Humanitarian Law 